\title{
Reversal of P-Glycoprotein and Multidrug Resistance-Associated Protein 1 Mediated Multidrug Resistance in Cancer Cells by HZ08 Isomers, Tetrataisohydroquinolin Derivatives
}

\author{
Fang YAN, ${ }^{a}$ Yi JiAng, ${ }^{b}$ Yun-Man LI, ${ }^{*}, a$ Xia Zhen, ${ }^{a}$ Juan CEN, ${ }^{a}$ and Wei-Rong FAnG ${ }^{a}$ \\ ${ }^{a}$ Department of Physiology, China Pharmaceutical University; 24 Tongjia Xiang, Nanjing 210009, Jiangsu, P. R. China: \\ and ${ }^{b}$ Shanghai Institute of Materia Medica; 555 Zu Chong Zhi Road, Zhang Jiang Hi-Tech Park, Pudong, Shanghai \\ 201203, P. R. China. $\quad$ Received August 9, 2007; accepted February 25, 2008; published online March 28, 2008
}

Overexpression of P-glycoprotein (Pgp) and multidrug resistance protein 1 (MRP1) by tumors results in multidrug resistance (MDR) to structurally unrelated anti-tumor agents. HZ08, a chiral compound, was a newly synthesized tetraisohydroquinoline derivative to reverse Pgp and MRP1 mediated MDR. In present studies, $\mathrm{R}, \mathrm{S}-\mathrm{HZO8}$ and their racemate reversed the resistance to adriamycin and vincristine of adriamycin-selected human leukemia (K562/ADM) cells that overexpress Pgp. R, S-HZ08 and their racemate modulated adriamycin cytotoxicity when R, S-HZ08 and their racemate were removed $12 \mathrm{~h}$ prior to the cytotoxicity assay. In addition, R, S-HZ08 and their racemate increased intracellular accumulation of Rhodamine123 in Caco-2 cells that overexpress Pgp. Furthermore, using a DNA content analysis and an annexin V binding assay, R, S-HZ08 and their racemate effectively reversed the resistance to adriamycin-induced apoptosis in K562/ADM cells. R, S-HZ08 and their racemate also moderately reversed the resistance to adriamycin and vincristine of MCF-7/ADM cells that overexpress MRP1. However, R, S-HZ08 and their racemate hardly affected intracellular glutathione (GSH) levels and glutathione S-transferase (GST) activities in MCF-7/ADM cells. The result showed that R, S-HZ08 and their racemate possibly reverse MDR1 mediated multidrug resistance by a direct interaction with MRP1, not interaction with MRP1 via GSH. Thus, R, S-HZ08 and their racemate should be useful for treating patients with tumors that overexpress both Pgp and MRP1.

Key words $\quad$ P-glycoprotein; multidrug resistance protein 1; multidrug resistance; HZ08

Multidrug reisitance (MDR) in cancer cells could lead to chemotherapeutic failure. The molecular mechanisms leading to MDR include the activation of transport and detoxification systems, enhancement of target repair activities, alterations of drug targets, and disregulation of cells death pathways. ${ }^{1)}$ MDR may be resulted from the overexpression of transporter proteins such as P-glycoprotein (Pgp), multidrug resistance associated protein 1 (MRP1), lung resistance protein (LRP), and breast cancer resistance protein (BCRP).,3) Pgp is a $170-\mathrm{kDa}$ transmembrane glycoprotein that is expressed in various MDR cell lines and that functions as an ATP-dependent drug efflux pump. ${ }^{4-6)}$ Pgp actively effluxes a wide range of structurally diverse amphipathic anticancer agents and Pgp-mediated MDR has also been associated with inhibition of multiple forms of casapase-dependent tumor cell apoptosis. ${ }^{7-9)}$ MRP1 is $190-\mathrm{kDa}$ membrane glycoprotein that is expressed in a wide range of tissues, clinical tumours and many non-Pgp-mediated MDR cell lines. ${ }^{10,11)}$ MRP1 transports a number of endogenous and exogenous organic anions and a wide variety of compounds conjugated to glutathione (GSH), glucuronate or sulphate. ${ }^{12)}$ Although MRP1 is a typical glutathione-S-conjugate (GS-X) pump, anticancer agents that not metabolized such as adriamycin and vincristine are also substrates for MRP1. ${ }^{13)}$ However, most efficacious agents that reverse Pgp-mediated MDR do not reverse MRP1-mediated such as LY335979. LY335979 (zosuquidar) is a third generation modulator of Pgp that has been ascribed to an 'ideal modulator' of Pgp-mediated multidrug resistance, but not a MRP1 modulator. ${ }^{14,15)}$ Indeed, MRP1 confers resistance to a variety of compounds like anthracycline, epipodophylotoxins and some Vinca alkaloids of which some are used as anticancer drugs in clinic. $\left.{ }^{16}\right)$

HZ08 (Fig. 1), a chiral compound, was designed and syn- thesized as a novel MDR modulators on the basis of tetraisohydroquinoline to reverse cancerous multidrug resistance, which has similar structure with verapamil but lower activity of $\mathrm{Ca}^{2+}$ channel than verapamil. The present studies were undertaken to evaluate the ability of R, S-HZ08 and their racemate to sensitize Pgp and MRP1 expressing cells to anticancer agents in vitro, to determine their effects on apoptosis induced by combining vincristine, and to evaluate their efficacy on GSH content and glutathione S-transferase (GST) activity. These results indicated that R, S-HZ08 and their racemate were efficacious on reversing Pgp and MRP1-mediated MDR due to strong activity of reversing multidrug resistance of cancer cells in vitro.

\section{MATERIALS AND METHODS}

Chemicals R, S-HZ08 and their racemate HZ08 were kindly provided by Prof. Wen-Long Huang (China Pharmaceutical University, Nanjing, China). Adriamycin, vincristine, verapamil, 3-(4,5-dimethylthiazol-2-yl)-2,5-diphenyl tetrazolium bromide (MTT) and other reagent grade chemi-

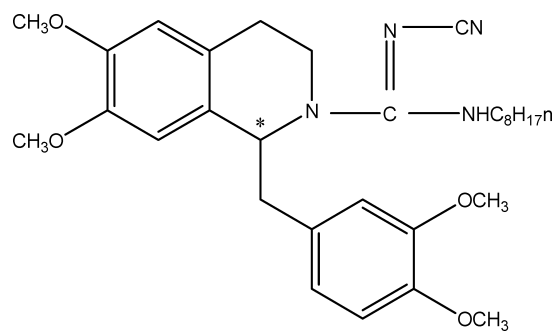

Fig. 1. The Chemical Structure of R, S-HZ08

* A chiral carbon atom. 
cals were purchased from Sigma/Aldich Co. (St. Louis, MO, U.S.A.). FITC-annexin V and propidium iodide (PI) were obtained from Becton Dichkinson (Franklin Lakes, NJ, U.S.A.). Cell culture media and supplements were products of Gibco BRL (Rockville, MD, U.S.A.).

Cell Lines Human leukemia cell line K562 and its adriamycin-selected Pgp-overexpressing subline K562/ADM were obtained from Institute of Hematology of Chinese Academy of Medical Sciences (Tianjin, China). Human intestinal cell line Caco-2, human breast cancer cell line MCF-7 and $\mathrm{MCF} / \mathrm{ADM}$ were kindly provided by National Center of New Drug Screening (China Pharmaceutical University, Nanjing, China) and Caco-2 was used at passages 24 to 40. K562, K562/ADM, MCF-7 and MCF-7/ADM cell lines were grown in RPMI 1640 medium containing 10\% bovine serum (FBS) and $100 \mathrm{U}$ antibiotics (benzylpenicillin sodium and gentamycin sulfate), at $37^{\circ} \mathrm{C}$ in a humidified $5 \% \mathrm{CO}_{2}$ incubator. To maintain MDR phenotype, $1 \mu \mathrm{g} / \mathrm{ml}$ adriamycin was added to $\mathrm{K} 562 / \mathrm{ADM}$ and MCF-7/ADM cultures and maintained in drug-free medium for at least $7 \mathrm{~d}$ before used. Caco- 2 cell line was grown in DMEM (4500 mg/l glucose) medium supplemented with $10 \%$ FBS and $100 \mathrm{U}$ antibiotics.

Cytotoxicity Assay Cell viability was determined using MTT. ${ }^{17)}$ Cells were harvested during logarithmic growth phase, and seeded in 96-well plates (Costar, Corning, NY, U.S.A.) at a density of $5 \times 10^{4}$ cells $/ \mathrm{ml}$. In the assays of drug resistant modulation and cytotoxic evaluation, the cells were then cultured for $48 \mathrm{~h}$ in the presence of anticancer agents with or without modulators. In the assay of drug effective duration, the cells were incubated $24 \mathrm{~h}$ with or without modulators before the addition of adriamycin. Modulators were added to the wells with the final concentrations from 1 to $10 \mu \mathrm{M}$. Cells were washed, incubated in growth medium for 0 to $24 \mathrm{~h}$, and exposed to varying anticancer drugs concentrations. After treatment of anticancer agents for $48 \mathrm{~h}, 20 \mu \mathrm{l}$ of freshly prepared MTT ( $5 \mathrm{mg} / \mathrm{ml}$ in PBS solution) was added to the wells and incubated for $4 \mathrm{~h}$ at $37^{\circ} \mathrm{C}$. Cells were centrifuged for $15 \mathrm{~min}$ at $3500 \mathrm{rpm}, 200 \mu \mathrm{l}$ of medium was carefully removed, and $120 \mu \mathrm{l}$ of dimethyl sulfoxide was added. Cells were shaken for 10 min until no particulate matter was visible. The absorbance was measured on a Bio-Rad Model/550 microplate reader (Hercules, CA, U.S.A.) with a test wavelength of $570 \mathrm{~nm}$. The concentrations required to inhibit growth by $50 \%$ ( $\mathrm{IC}_{50}$ values) were calculated from the cytotoxicity curved using a Bliss's software. The fold-reversal of MDR (RF) was calculated by dividing $\mathrm{IC}_{50}$ values in the absence of Pgp inhibitors by those in the presence of Pgp inhibitors.

Rhodamine123 Accumulation Assay Caco-2 cells during logarithmic growth phase were seeded in 24-well plates (Costar) at a density of $2 \times 10^{6}$ cells $/ \mathrm{ml}$ and incubated for $24 \mathrm{~h}$ at $37^{\circ} \mathrm{C}$. The medium was carefully removed and replaced by $400 \mu \mathrm{l}$ of cell culture medium containing $5 \mu \mathrm{M}$ Rhodamine123 (Rh123) and various concentrations of modulators. After an additional $3 \mathrm{~h}$ incubation at $37^{\circ} \mathrm{C}$, the medium was aspirated, cells were washed by ice-cold PBS solution twice, and 1\% Tition X-100 solution (in PBS) was added. After cells were broken up, the fluorescent density was determined on a TECAN Safire ${ }^{2}$ plate reader (Zürich, Switzerland) by fluorescence spectrophotometric method with an excitation of $488 \mathrm{~nm}$ and an emission of $535 \mathrm{~nm}$. The concentrations of Rh123 (nM/g protein) were calculated from protein content of each well and a standard curve with fluorescent density and various concentrations.

Flow Cytometric Apoptosis Assay and Cell Cycle Analysis DNA content analysis and Annexin V binding assay were selected to evaluate reversing MDR effects of $\mathrm{R}, \mathrm{S}-\mathrm{HZ} 08$ and their racemate on the cell cycle and apoptosis in K562 and K562/ADM cells. The procedure of cell cycle analysis was described by Nicoletti et al. ${ }^{18)}$ Following incubation with or without modulators of various concentrations at $10 \mu \mathrm{M}$ adriamycin for $48 \mathrm{~h}, 1 \times 10^{6}$ cells were harvested and fixed in $70 \%$ cold ethanol at $4{ }^{\circ} \mathrm{C}$ for $12 \mathrm{~h}$. Thereafter, cells were washed with PBS twice, resuspended in $150 \mu \mathrm{l}$ of $100 \mu \mathrm{g} / \mathrm{ml}$ RNase solution (in $0.2 \mathrm{M}$ citrate-phosphate buffer, $\mathrm{pH}$ 7.8), and incubated for $30 \mathrm{~min}$ at $37^{\circ} \mathrm{C}$. Finally, cells were stained with $100 \mu \mathrm{g} / \mathrm{ml}$ PI solution at room temperature in the dark. The fluorescence activity of the remaining DNA content was analyzed on a Becton-Dickinson FACScan instrument.

The assay of apoptosis was carried out according to the protocol of Alexis Biochemicals (San Diego, CA, U.S.A.). ${ }^{19)}$ Cells treated with or without modulator of various concentrations at $10 \mu \mathrm{M}$ adriamycin for $24 \mathrm{~h}$, were harvested by centrifugation, washed with PBS twice, and resuspended in $250 \mu \mathrm{l}$ of binding buffer. Five microlitres of Annexin V-FITC was added to each sample, and incubated at room temperature for $10 \mathrm{~min}$ in the dark. Finally, cells were washed with binding buffer, resuspended in $190 \mu \mathrm{l}$ of binding buffer and $10 \mu \mathrm{l}$ of PI solution (final concentration of $1 \mathrm{mg} / \mathrm{ml}$ ). The samples were measured on a flow cytometry with CellQuest software (Becton Dickinson). The proportion of apoptotic cells was estimated by percentage of cells stained positive for Annexin $\mathrm{V}$ while remaining impermeable to PI (Annexin $\mathrm{V}+$ and $\mathrm{PI}-$ ); necrosis was determined as positive stain with both Annexin V and PI (Annexin V+ and PI+); and viability was defined as Annexin V- and PI-

GSH Assay The contents of total cellular glutathione (GSH) in MCF-7 and MCF-7/ADM cells were measured according to Tietze's method. ${ }^{20)}$ Briefly, $5 \times 10^{6}$ cells were harvested, washed twice with ice-cold PBS and suspended in $125 \mathrm{~mm}$ sodium phosphate buffer containing $5 \mathrm{~mm}$ EDTA (pH 7.5). After sonicated, 10\% 5-sulfsulicylic acid was added to the samples, and precipitated for $2 \mathrm{~h}$ at $4{ }^{\circ} \mathrm{C}$. Cells were centrifuged for $15 \mathrm{~min}$ at $10000 \mathrm{rpm}$ to obtain protein-free solution. The reaction system of determining GSH in cells consisted of $0.3 \mathrm{~mm}$ NADPH, $6 \mathrm{~mm} 5,5^{\prime}$-dithiobis-(2-nitrobenzoic acid), and 0.5 unit of GSH reductase. After 5 min of incubation, samples were determined at $412 \mathrm{~nm}$ on spectrophotometry. The content of GSH was calculated from the absorbance of a standard.

GST activities with 1-chloro-2,4-dinitrobenzene (CDNB) were measured by monitoring the formation of the conjugate of CDNB (1 mM) and GSH (1 mM) at $340 \mathrm{~nm}$ according to Habig et $a .^{21)}$ An aliquot of $1 \times 10^{7}$ cells was harvested, washed twice with ice-cold PBS, and resuspended in $10 \mathrm{~mm}$ Tris- $\mathrm{HCl}(\mathrm{pH} 7.8)$ containing $0.2 \mathrm{M} \mathrm{NaCl}$. After sonication, the samples were centrifuged at $10000 \mathrm{rpm}$ for $30 \mathrm{~min}$ at $4{ }^{\circ} \mathrm{C}$. The supernatant was analyzed for GSH activity using thiotepa or monoglutathionylthiotepa in a spectrophotometric assay. After incubation of GST and thiotepa or monoglutathionylthiotepa for $15 \mathrm{~min}$, the remaining GST activities in 
the reaction mixture were determined. Reactions were initiated by the addition of CNDB and GSH, and S-(2,4-dinitrophenyl) glutathione (DNP-SG) formation was monitored at $340 \mathrm{~nm}$ for $2 \mathrm{~min}$. The enzymatic activities were expressed in $\mathrm{nm} / \mathrm{min} / \mathrm{mg}$ protein.

\section{RESULTS}

Modulation of Drug Resistance The effect of R, SHZ08 and their racemate on the cytotoxicity of two clinically used anticancer drugs, vincristine and adriamycin, was examined. Adriamycin resistant phenotype of human leukemia cell line, K562/ADM previously shown to overexpress Pgp and not MRP1 and BCRP by RT-PCR method (data not shown), was used to investigate the activities of R, S-HZ08 and their racemate of modulating Pgp. Moreover, MCF7/ADM, adriamycin resistant phenotype of human breast cancer cell line showed to overexpress only MRP1 protein and GSH not Pgp and BCRP by RT-PCR (data not shown), was selected to evaluate the activities of three compounds of modulating MRP1. The effectiveness of the modulator was calculated as the 'fold shift', which is the ratio of the $\mathrm{IC}_{50}$ measured in the presence and the absence of the modulators (shown in Materials and Methods) and was compared to other Pgp modulator, verapamil. ${ }^{22)}$ As shown in Fig. 2, R, SHZ08 and HZ08 were highly active across the panel of cell lines and gave significant reversal of resistance to vincristine and adriamycin in K562/ADM and MCF-7/ADM cells at concentrations of $1,10 \mu \mathrm{M}$. And R-HZ08 and their racemate were about $1-3$ folds potent than verapamil in reversing resistance to adriamycin and vincristine in K562/ADM and MCF-7/ADM cells. And S-HZ08 was weaker potent than verapamil and about 0.8 fold. Moreover, the potency of RHZ08 was 2-3 folds greater than that of S-HZ08 and their racemate. In contrast, verapamil, R, S-HZ08 and their racemate, at the concentrations tested, displayed minimal modulatory activity against the drug-sensitive parental cells K562 and MCF-7 with reversal folds of $1-2$ (data not shown). The results showed that R, S-HZ08 and their racemate were potent at reversing resistance to various agents associated with Pgp and MRP1 protein in K562/ADM and MCF7/ADM cells and R-HZ08 was more effective than S-HZ08 and HZ08 in these assays.

Cytotoxicity of HZ08 Isomers Alone To examine that the enhanced cytotoxicity with R, S-HZ08 and their racemate in the assay of modulation of drug resistance was due to modulation and not due to cytotoxicity of the modulators themselves, the percentages of viability were determined for both the parental and resistant cells used above. After cells were treated with $100 \mu \mathrm{M} \mathrm{R}, \mathrm{S}-\mathrm{HZ} 08$ and their racemate for $48 \mathrm{~h}$, the cellular viability was hardly influenced (Fig. 3). These data show that R, S-HZ08 and their racemate were nontoxic at the concentration needed to reverse drug resistance in vitro.

Duration of Drug Effect To further evaluate the effective duration of R, S-HZ08 and their racemate, K562/ADM cells were incubated with the modulators for $24 \mathrm{~h}$, washed to remove the modulators and incubated for various periods in the absence of the reversal agents prior to the addition of adriamycin. Table 1 summarizes the results. The reversal effect of $10 \mu \mathrm{M}$ R, S-HZ08 and their racemate all persisted
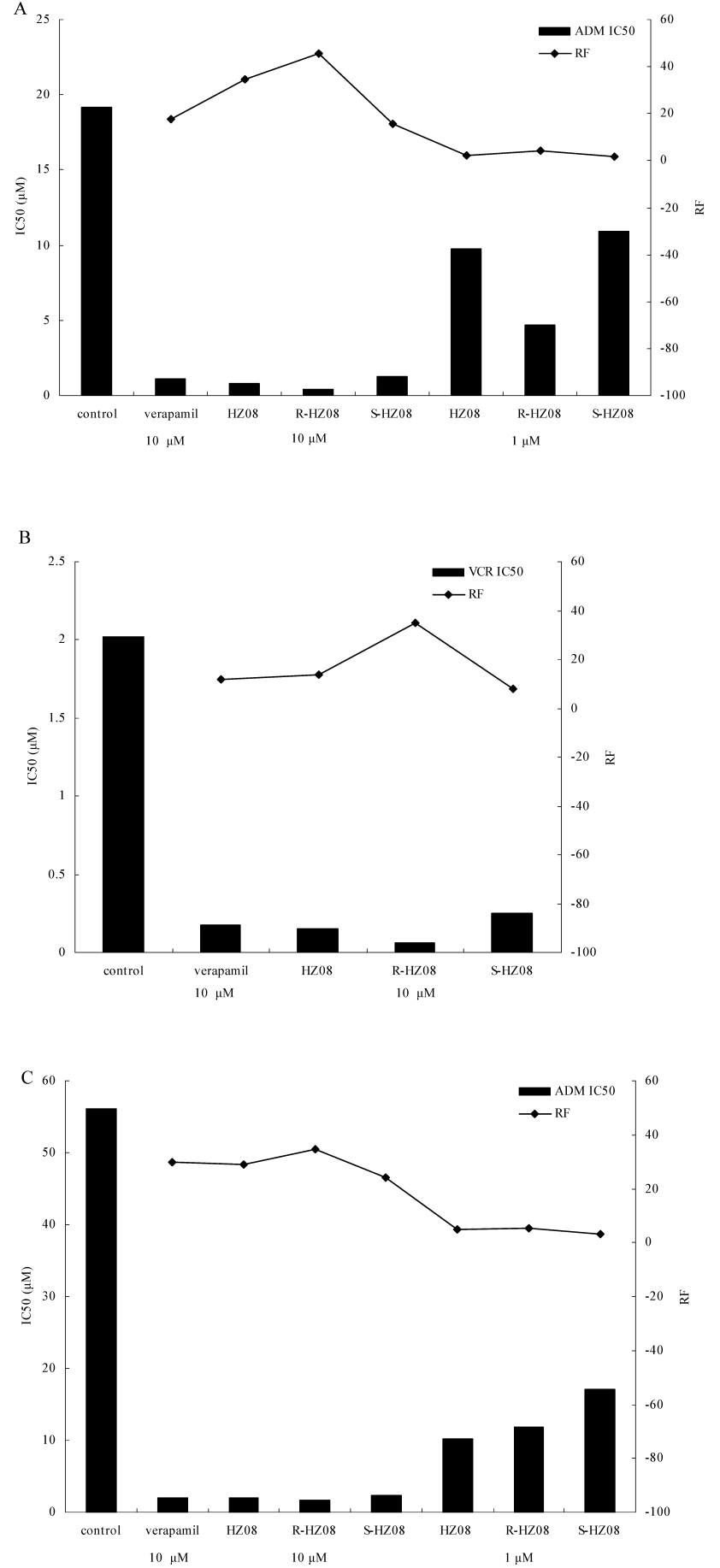

Fig. 2. Effects of R, S-HZ08 and Their Racemate on Cytotoxicity of Adriamycin or Vincristine in K562/ADM and MCF-7/ADM Cells

K562/ADM cells were co-treated with various concentrations of adriamycin (A) and with various concentrations of vincristine (B) in the presence of $1,10 \mu \mathrm{M}$ R, S-HZ08 and their racemate for $48 \mathrm{~h}$. MCF-7/ADM cells were co-treated with various concentrations of adriamycin in the presence of $1,10 \mu \mathrm{M} \mathrm{R}, \mathrm{S}-\mathrm{HZ} 08$ and their racemate for $48 \mathrm{~h}$ (C). The treatments of R, S-HZ08 and their racemate enhanced the cytotoxicity of adriamycin or vincristine in K562/ADM and MCF-7/ADM cells. Verapamil $(10 \mu \mathrm{M})$ was used as a positive control and cell cytotoxicity was determined using the MTT assay as described in Materials and Methods. The fold-reversal of MDR (RF) was calculated by dividing $\mathrm{IC}_{50}$ values in the absence of Pgp inhibitors by those in the presence of Pgp inhibitors.

throughout the 6-h time period. However, when cells were incubated with $1 \mu \mathrm{m} \mathrm{S}-\mathrm{HZ} 08$, a significant reduction in modulatory activity was observed after washing. Under these conditions, better activity of R-HZ08 $(1,10 \mu \mathrm{M})$ was seen 
Table 1. Duration of Effects of R, S-HZ08 and Their Racemate on Adriamycin Cytotoxicity in K562/ADM Cells

\begin{tabular}{|c|c|c|c|c|c|c|c|c|}
\hline \multirow{3}{*}{$\begin{array}{l}\text { Treatment } \\
\text { schedule }\end{array}$} & \multicolumn{8}{|c|}{$\mathrm{IC}_{50}(\mu \mathrm{g} / \mathrm{ml})$} \\
\hline & \multirow{2}{*}{ Control $^{a)}$} & \multirow{2}{*}{$\begin{array}{c}\text { Verapamil } \\
10 \mu \mathrm{M}\end{array}$} & \multicolumn{2}{|c|}{$\mathrm{HZ} 8^{b)}$} & \multicolumn{2}{|c|}{ R-HZ08 ${ }^{c)}$} & \multicolumn{2}{|c|}{$\mathrm{S}-\mathrm{HZ} 08^{d)}$} \\
\hline & & & $1 \mu \mathrm{M}$ & $10 \mu \mathrm{M}$ & $1 \mu \mathrm{M}$ & $10 \mu \mathrm{M}$ & $1 \mu \mathrm{M}$ & $10 \mu \mathrm{M}$ \\
\hline & $>20$ & & & & & & & \\
\hline No wash $0 \mathrm{~h}$ & & 1.15 & 9.19 & 0.88 & 3.73 & 0.52 & 11.18 & 1.41 \\
\hline Wash $0 \mathrm{~h}$ & & $>20$ & 10.24 & 1.79 & 4.06 & 1.21 & 15.47 & 3.73 \\
\hline Wash $1 \mathrm{~h}$ & & & 13.78 & 2.69 & 6.37 & 1.96 & 19.06 & 5.32 \\
\hline Wash $3 \mathrm{~h}$ & & & 15.27 & 4.35 & 11.87 & 3.77 & $>20$ & 11.59 \\
\hline Wash $5 \mathrm{~h}$ & & & 17.1 & 8.92 & 17.93 & 6.31 & & 18.72 \\
\hline Wash $8 \mathrm{~h}$ & & & $>20$ & 14.41 & $>20$ & 12.59 & & $>20$ \\
\hline Wash $12 \mathrm{~h}$ & & & & $>20$ & & 18.26 & & \\
\hline
\end{tabular}

a) Cells were treated with adriamycin only. b) Cells were treated with adriamycin and HZ08. c) Cells were treated with adriamycin and R-HZ08. d) Cells were treated with adriamycin and S-HZ08.

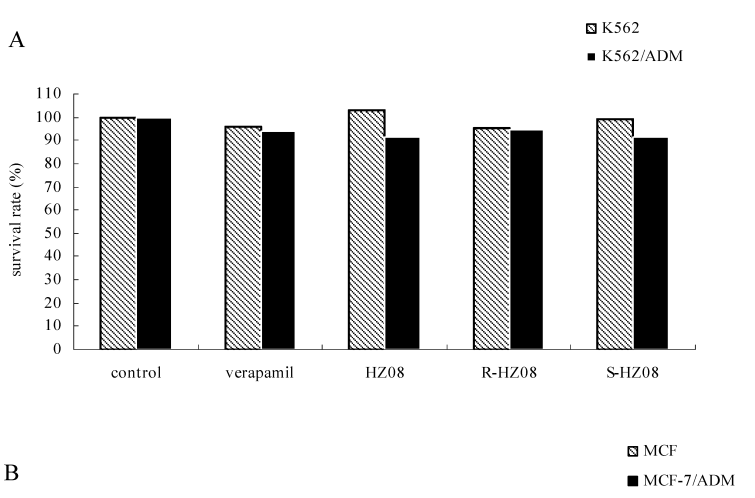

B

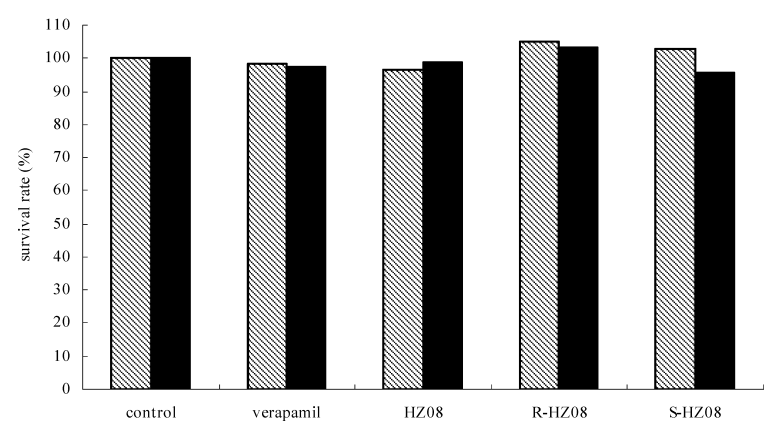

Fig. 3. Effects of R, S-HZ08 and Their Racemate Alone on Cell Viability of K562/ADM and MCF-7/ADM Cells

K562/ADM, the parental cells (A) and MCF-7/ADM, the parental cells (B) were treated with $100 \mu \mathrm{M} \mathrm{R}, \mathrm{S}-\mathrm{HZ} 08$ and their racemate for $48 \mathrm{~h}$. R, S-HZ08 and their racemate alone treatments had no effect on cell viability of K562/ADM and MCF-7/ADM cells at the concentration needed to reverse drug resistance in vitro. Verapamil was applied at concentration of $10 \mu \mathrm{M}$ and cell cytotoxicity was determined using the MTT assay as described in Materials and Methods.

than S-HZ08 and their racemate. By contrast, the modulatory activity of verapamil used as a comparator disappeared immediately after its removal from the medium. The results indicated that R, S-HZ08 and their racemate had the long duration of action in contrast to that observed with $10 \mu \mathrm{M}$ verapamil.

Effect on Rhodamine123 Accumulation Transport assays were conducted to analyze the effects of R, S-HZ08 and their racemate on the accumulation of Rh123, a fluorescent Pgp substrate, in Caco- 2 cells with high Pgp expression by fluorescence spectrophotometric method. Co-administration of R, S-HZ08 and their racemate markedly enhanced the Rh123 accumulation in Caco-2 cells and R-HZ08 had stronger

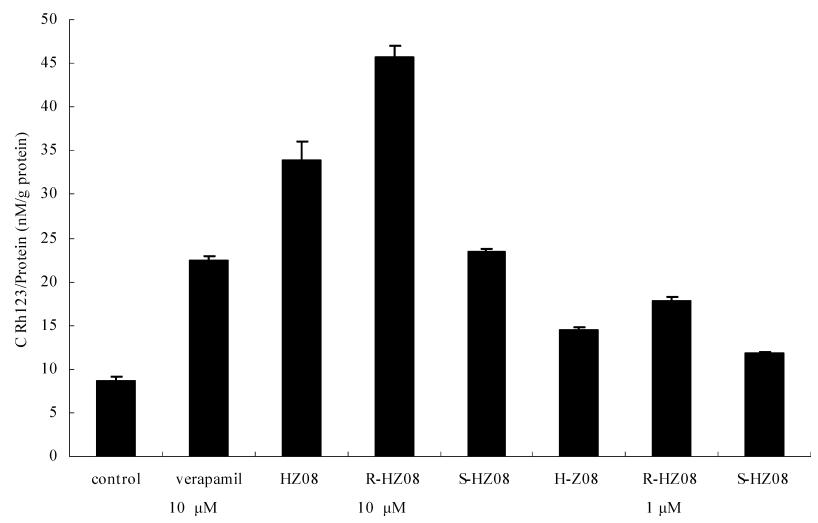

Fig. 4. Effects of R, S-HZ08 and Their Racemate on Accumulation of Rhodamine 123 (Rh123) in Caco-2 Cells

Caco- 2 cells were incubated with $5 \mu \mathrm{M}$ Rh123 alone or in combination with $1,10 \mu \mathrm{M}$ $\mathrm{R}, \mathrm{S}-\mathrm{HZ} 08$ or $10 \mu \mathrm{M}$ verapamil for $3 \mathrm{~h}$ and collected for the determination of intracellular Rh123. R, S-HZ08 and their racemate enhanced the accumulation of Rh123 in Caco- 2 cells. Data are mean \pm S.D. of three independent experiments.

effects than those of S-HZ08 and their racemate at the same concentration (Fig. 4). Moreover, R-HZ08 and their racemate were more effective on enhancing the Rh123 accumulation than verapamil at $10 \mu \mathrm{M}$. The results showed that $\mathrm{R}, \mathrm{S}-\mathrm{HZ} 08$ and their racemate could effectively increase the intracellular concentration of Rh123 in Caco- 2 cells.

Apoptosis Induced by Combining Adriamycin and HZ08 Isomers Adriamycin is topoisomerase II inhibitor which induces G2/M arrest in cell cycle. R, S-HZ08 and their racemate, at concentration as high as $100 \mu \mathrm{M}$, had no effect on the cell cycles of K562 and K562/ADM (data not shown). As shown in Table $2,10 \mu \mathrm{M}$ adriamycin showed slight effect on the cell cycle of K562/ADM, while the treatment of various concentrations of $\mathrm{R}, \mathrm{S}-\mathrm{HZ} 08$ and their racemate led to a significant increase in cell population at the G2/M phase and a decrease in the cells at $\mathrm{G} 1$ and $\mathrm{S}$ phase. At $10 \mu \mathrm{M}, \mathrm{R}-\mathrm{HZ} 08$ was more effective on increasing the percentage of $\mathrm{G} 2 / \mathrm{M}$ phase than verapamil. And adriamycin-induced G2/M arrest was more significantly increased by R-HZ08 than S-HZ08 and their racemate at the same concentrations.

The appearance of sub-diploid phase is a specific marker of apoptosis; necrosis induced by metabolic poisons or lysis produced by complement did not induce any sub-diploid phase in the DNA fluorescence histogram. The results showed that the percentage of sub-diploid phase induced by 
Table 2. Effects of R, S-HZ08 and Their Racemate on Sub-diploid Phase and G2/M Arrest Induced by $10 \mu \mathrm{M}$ Adriamycin in K562/ADM Cells

\begin{tabular}{lccc}
\hline \hline Group & $\begin{array}{c}\text { Concentration } \\
(\mu \mathrm{M})\end{array}$ & $\begin{array}{c}\text { Sub-diploid } \\
(\%)\end{array}$ & G2/M phase $(\%)$ \\
\hline Control & 0 & $2.65 \pm 0.29$ & $34.71 \pm 2.75$ \\
Verapmil & 10 & $6.34 \pm 1.27$ & $56.35 \pm 2.61$ \\
R-HZ08 & 10 & $9.16 \pm 1.08$ & $61.57 \pm 2.25$ \\
S-HZ08 & 10 & $5.43 \pm 1.41$ & $51.77 \pm 3.69$ \\
HZ08 & 10 & $6.98 \pm 2.74$ & $56.75 \pm 2.16$
\end{tabular}

Data are mean \pm S.D. of three independent experiments

adriamycin in K562/ADM was greatly enhanced in the presence of R, S-HZ08 and their racemate (Table 2). After the cells were treated with $10 \mu \mathrm{M}$ adriamycin combined with $10 \mu \mathrm{M}$ R-HZ08 for $48 \mathrm{~h}$, the sub-diploid phase percentages of K562/ADM cells were 1.5 fold higher than that treated with adriamycin alone and with adriamycin and verapamil. In sensitive K562 cells, R, S-HZ08 and their racemate had no significant effects on the percentages of sub-diploid phase by adriamycin (data not shown).

Previous reports suggest that Pgp can protect the cells from various anticancer drugs inducing apoptosis. To evaluate the reversal effect of $\mathrm{R}, \mathrm{S}-\mathrm{HZ} 08$ and their racemate on the resistance to apoptosis in K562/ADM cells, annexin-V binding assay was selected. When cell death occurs in the early phase of apoptotic cell death, phosphatidylserine is translocated from the inner side of the plasma membrane to the out layer. Moreover, annexin- $\mathrm{V}$ is $\mathrm{Ca}^{2+}$ dependent phospholipidbinding protein with high affinity for phosphatidylserine. Therefore, the method of annexin-V binding with PI staining provided a pathway to detect apoptotic cells and to discriminate between apoptosis and necrosis. As Fig. 5 showed, the apoptotic percentages of K562/ADM cells induced by $10 \mu \mathrm{M}$ adriamycin with modulators had a more significant increase than that by adriamycin alone. And R-HZ08 was more effective on increasing the apoptotic percentages than verapamil at $10 \mu \mathrm{M}$. Moreover, better activity of R-HZ08 was seen than those of S-HZ08 and their racemate at various concentrations. Co-treatment with $\mathrm{R}, \mathrm{S}-\mathrm{HZ} 08$ and their racemate significantly enhanced $\mathrm{G} 2 / \mathrm{M}$ arrest and dramatically increased apoptotic rates of K562/ADM cells induced by adriamycin but not in drug-sensitive cells (Pgp non-expressing), which further confirmed that $\mathrm{R}, \mathrm{S}-\mathrm{HZ} 08$ and their racemate effectively reverse Pgp-mediated multidrug resistance in cancer cells.

Effect on GSH Contents and GST Activities It has been reported that the functions of MRP1 was associated with GSH and GST. ${ }^{23,24)}$ The GSH contents and the GST activities were therefore measured in MCF-7/ADM cells and parental cells. The levels of GSH in the cells were normalized to the amount of total cellular protein. As shown in Fig. 6 , the cellular GSH content was about 1.6-fold higher in MCF-7/ADM cells than that in MCF-7 cells. The cellular GSH contents were measured after $48 \mathrm{~h}$ in the presence or absence of verapamil, R, S-HZ08 and their racemate at $10 \mu \mathrm{M}$. The cellular GSH concentrations were not different between untreated control MCF-7/ADM cells and treated MCF-7/ADM cells with R, S-HZ08 and their racemate (Fig. 6A). However, GSH levels decreased significantly after $48 \mathrm{~h}$ treatment of verapamil in MCF-7/ADM from 122.13 \pm 10.65
A control

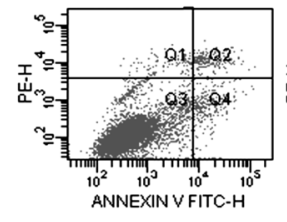

apoptosis: $2.9 \pm 0.6 \%$

D $10 \mu \mathrm{M}$ adriamycin plus $10 \mu \mathrm{M} \mathrm{S}-\mathrm{HZ} 08$

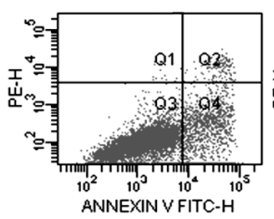

apoptosis: $16.0 \pm 1.2 \%$

$\mathrm{G} 10 \mu \mathrm{M}$ adriamycin plus $1 \mu \mathrm{M}$ S-HZ08

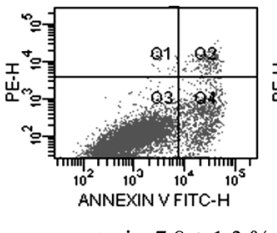

apoptosis: $7.8 \pm 1.3 \%$
B $10 \mu \mathrm{M}$ adriamycin alone

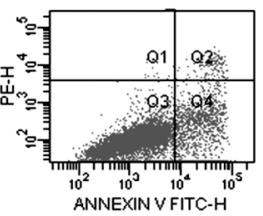

apoptosis: $6.6 \pm 1.4 \%$

E $10 \mu \mathrm{M}$ adriamycin plus $10 \mu \mathrm{M} \mathrm{HZ08}$

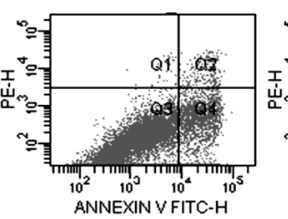

apoptosis: $19.4 \pm 3.4 \%$

$\mathrm{H} 10 \mu \mathrm{M}$ adriamycin plus $1 \mu \mathrm{M} \mathrm{HZ08}$

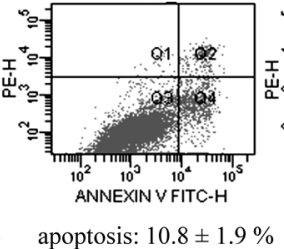

$\mathrm{C} 10 \mu \mathrm{M}$ adriamycin plus $10 \mu \mathrm{M}$ verapamil

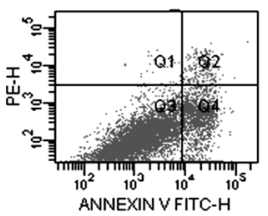

apoptosis: $21.2 \pm 2.7 \%$

F $10 \mu \mathrm{M}$ adriamycin plus $10 \mu \mathrm{M}$ R-HZ08

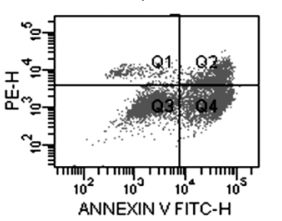

apoptosis: $33.0 \pm 4.3 \%$

I $10 \mu \mathrm{M}$ adriamycin plus $1 \mu \mathrm{M}$ R-HZ08

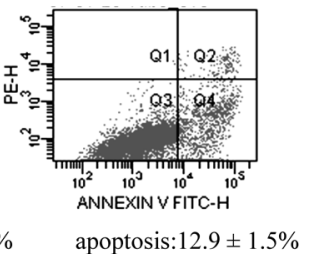

Fig. 5. Effects of R, S-HZ08 and Their Racemate on Adriamycin-Induced Apoptosis in K562/ADM Cells

$\mathrm{R}, \mathrm{S}-\mathrm{HZ} 08$ and their racemate increased adriamycin-induced apoptosis in K562/ADM cells. Data are mean \pm S.D. of three independent experiments. Q2 contains dead cells (late apoptotic and necrosis cells) and Q3 and Q4 contain viable and apoptotic cells, respectively.

$\mu \mathrm{g} / \mathrm{mg}$ protein to $71.98 \pm 12.06 \mu \mathrm{g} / \mathrm{mg}$ protein.

As for GST activities, MCF-7/ADM cells contained 72.98土 $3.86 \mathrm{U} / \mathrm{mg}$ protein, as compared with $51.62 \pm 3.15 \mathrm{U} / \mathrm{mg}$ protein in the parental cells. After $48 \mathrm{~h}$ treatment in the presence or absence of $\mathrm{R}, \mathrm{S}-\mathrm{HZ} 08$ and their racemate at $10 \mu \mathrm{M}$, glutathione S-transferase activities were not significantly different. But the $48 \mathrm{~h}$ incubation with verapamil significantly decreased the GST activities in MCF-7/ADM cells comparing to the corresponding untreated cells (Fig. 6B).

\section{DISCUSSION}

The failure of the curative treatment of cancer patients often occurs as a result of intrinsic or acquired drug resistance of the tumor to chemotherapeutic agents. The resistance of tumors occurs not only to a single cytotoxic drug used, but also occurs as a cross-resistance to a whole range of drug with different structures and cellular targets, which is called MDR. MDR severely limits the effectiveness of chemotherapy in a variety of common malignancies and is responsible for overall poor efficacy of cancer chemotherapy. ${ }^{25-27)}$ Overexpression of $\mathrm{ABC}$ transporters has been shown to be responsible for MDR. ${ }^{26)}$ The most typical ABC transporters in the cell membrane is Pgp, which is responsible for transporting various xenobiotics including anticancer drug out of cells by using ATP. Besides Pgp, MRP1 causing MDR in mammalian cells was observed in non-Pgp MDR cell lines. In fact, both the structure and drug resistance spectra of MRP1 

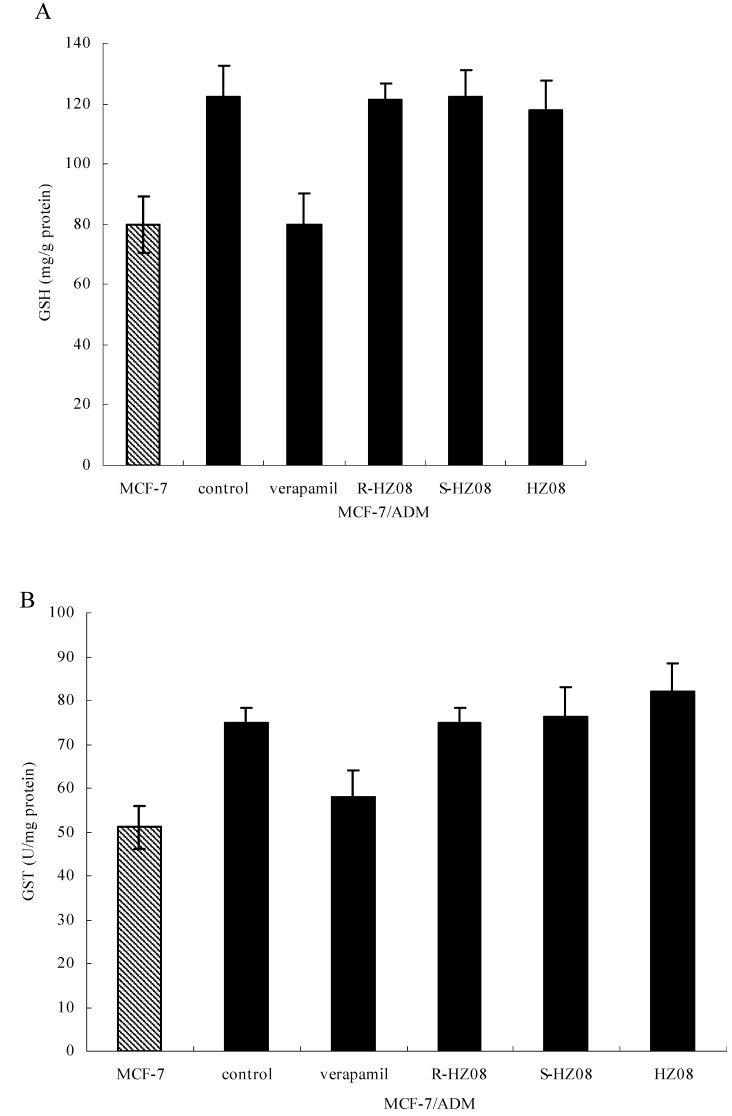

Fig. 6. Effects of R, S-HZ08 and Their Racemate on GSH Contents and GST Activities in MCF-7/ADM Cells

MCF-7/ADM and MCF-7 cells were treated with or without different modulators (concentration of $10 \mu \mathrm{M}$ ) for $48 \mathrm{~h}$ and harvested for the determination of GSH contents (A) and GST activities (B). R, S-HZ08 and their racemate did not affect the contents of GSH and the activities of GST in MCF-7/ADM cells. Data are mean \pm S.D. of three independent experiments.

and Pgp are similar except taxanes which are poor substrates for MRP1. MRP1 has also been widely accepted to cause clinical drug resistance. ${ }^{28)}$

One strategy for reversal of MDR in cells expressing ABC transporters is combined use of anticancer drugs with modulators. $^{29)}$ Inhibitors of ABC transporters, like Pgp and MRP1, can be used to enhance effects of anticancer drugs in MDR patients. In these studies, we have tested the abilities of $\mathrm{R}$, S-HZ08 and their racemate to reverse MDR mediated by Pgp and MRP1 by MTT method in K562/ADM and MCF7/ADM cell lines. The results showed that R, S-HZ08 and their racemate were efficacious modulators of Pgp and MRP1. However, it was also shown that the magnitude of Pgp and MRP1 inhibition by R-HZ08 was slightly greater than their racemate and S-HZ08, for which the reason perhaps lies in the difference of tridimensional structures between R-HZ08 and S-HZ08.

Studies were conducted to examine the effects of R, SHZ08 and their racemate on Rh123 accumulation, a known Pgp substrate, in Caco-2 cells. Caco-2, human intestinal cell line, has been shown to exhibit the morphological and function characteristics of normal enterocytes and expresses Pgp at the apical membrane. ${ }^{30)}$ The modulators significantly increase the accumulation of Rh123 in Caco- 2 cells. These results are consistent with the observation that R, S-HZ08 and their racemate are very potent at reversing anticancer drugs in K562/ADM cells overexpressing Pgp. The findings of drugs cytotoxicity and accumulation in K562/ADM and Caco-2 cell lines overexpressing Pgp are strongly indicated that the reversal of multidrug resistance by R, S-HZ08 and their racemate is probably attributable to the inhibition of Pgp-mediated efflux. Furthermore, co-treatments with R, SHZ08 and their racemate significantly enhanced G2/M arrest and dramatically increased apoptotic rates of K562/ADM cells induced by adriamycin but not in drug-sensitive cells (Pgp non-expressing), which further confirmed that R, SHZ08 and their racemate effectively reversed Pgp-mediated multidrug resistance in cancer cells.

Contrary to Pgp case, the MRP1-mediated active transport of unmodified chemotherapeutic drugs, such as adriamycin and vincristine, requires the presence of GSH as well as ATP ${ }^{31-34)} \mathrm{GSH}$ appears to play a role in facilitating the transport process, possibly by conjugation process or most probably by co-transport with other molecules. One of several ways of affecting MRP1 mediated transport is indirect interaction with GSH (GSH depletion, GST activities) and it is known that depletion of intracellular GSH levels can decrease the transport of several substrates. ${ }^{35-37)}$ In order to obtain insight in the possible mechanism of R, S-HZ08 and their racemate reversing MRP1-mediated drugs efflux, GSH contents and GST activities were measured in our studies. It is reported that when significant chemosensitization of MRP1 overexpressing cells by verapamil is observed, it may be more related to the abilities of verapamil to stimulate GSH efflux and reduce intracellular GSH levels than direct inhibition of the transporter itself. ${ }^{38-41)}$ And administration of verapamil decreased the GSTs activities of resistant cancer cells and no effect was observed on sensitive cancer cells. $^{42)}$ In contrast to verapamil, R, S-HZ08 and their racemate hardly affected intracellular GSH levels and GST activities in MCF-7/ADM cells, which showed that a direct interaction with the MRP1 is a possible mechanism of R, S-HZ08 and their racemate reversing MDR1 mediated multidrug resistance, not indirect interaction on MRP1 via GSH and GST, different from verapamil.

Our present studies provided evidents that R, S-HZ08 and their racemate had strong MDR reversal effects that might be a valuable adjunct to chemotherapy to decrease Pgp and MRP1 mediated resistance. However, the mechanisms of $\mathrm{R}, \mathrm{S}-\mathrm{HZ} 08$ and their racemate reversing Pgp and MRP1 mediated MDR in cancer cells were not yet elucidated, which were emphases of our next studies.

Acknowledgement This work was supported by Chinese National High Technology "863" Programs (Grant No. 2002AA233071).

\section{REFERENCES}

1) Szakács G., Paterson J. K., Ludwig J. A., Booth-Genthe C., Gottesman M. M., Nat. Rev. Drug Discov., 5, 219-234 (2006).

2) Tan B., Piwnica-Worms D., Ratner L., Curr. Opin. Oncol., 12, 450458 (2000).

3) Gottesman M. M., Fojo T., Bates S. E., Nat. Rev. Cancer, 2, 48-58 (2002).

4) Safa A. R., Glover C. J., Sewell J. L., Meyers M. B., Biedler J. L., Felsted R. L., J. Biol. Chem., 262, $7884-7888$ (1987).

5) Akiyama S., Cornwell M. M., Kuwano M., Pastan I., Gottesman M. 
M., Mol. Pharmacol., 33, 144-147 (1988).

6) Ford J. M., Hait W. N., Pharmcol. Rev., 42, 155-199 (1990).

7) Cumming R. C., Liu J. M., Youssoufian H., Buchwald M., Blood, 88, 4558-4567 (1996).

8) Smyth M. J., Krasovskis E., Sutton V. R., Johnstone R. W., Proc. Natl. Acad. Sci. U.S.A., 95, 7024-7029 (1998).

9) Notarbartolo M., Cervello M., Dusonchet L., Cusimano A., D’Alessandro N., Cancer Lett., 180, 91-101 (2002).

10) Cole S. P., Can. J. Physiol. Pharmacol., 70, 313-329 (1992).

11) Szakács G., Annereau J. P., Lababidi S., Shankavaram U., Arciello A., Bussey K. J., Reinhold W., Guo Y., Kruh G. D., Reimers M., Weinstein J. N., Gottesman M. M., Cancer Cell, 6, 129-137 (2004).

12) Jedlitschky G., Leier I., Buchholz U., Barnouin K., Kurz G., Keppler D., Cancer Res., 56, 988-994 (1996).

13) Haimeur A., Conseil G., Deeley R. G., Cole S. P., Curr. Drug Metab., 5, 21-53 (2004).

14) Starling J. J., Shepard R. L., Cao J., Law K. L., Norman B. H., Kroin J. S., Ehlhardt W. J., Baughman T. M., Winter M. A., Bell M. G., Shih C., Gruber J., Elmquist W. F., Dantzig A. H., Adv. Enzyme Regul., 37, 335-347 (1997).

15) Dantzig A. H., Shepard R. L., Gillespie J. S., Binkley S. N., Kuhfeld M. T., Starling J. J., Wrighton S. A., J. Pharmacol. Exp. Ther., 290, 854-862 (1999)

16) Borst P., Elferink R. O., Annu. Rev. Biochem., 71, 537-592 (2002).

17) Heo D. S., Park J. G., Hata K., Day R., Herberman R. B., Whiteside T. L., Cancer Res., 50, 3681-3690 (1990).

18) Nicoletti I., Migliorati G., Pagliacci M. C., Grignani F., Riccardi C., J. Immunol. Methods, 139, 271-279 (1991).

19) Koopman G., Reutelingsperger C. P., Kuijten G. A., Keehnen R. M., Pals S. T., Oers van M. H., Blood, 84, 1415-1420 (1994).

20) Tietze F., Anal. Biochem., 27, 502-522 (1969).

21) Habig W. H., Pabst M. J., Jakoby W. B., J. Biol. Chem., 249, 71307139 (1974).

22) Pearce H. L., Safa A. R., Bach N. J., Winter M. A., Cirtain M. C., Beck W. T., Proc. Natl. Acad. Sci. U.S.A., 86, 5128-5132 (1989).

23) Zaman G. J., Lankelma J., Tellingen Van O., Beijnen J., Dekker H., Paulusma C., Elferink Oude R. P., Baas F., Borst P., Proc. Natl. Acad. U.S.A., 92, 7690-7694 (1995).
24) Lutzky J., Astor M. B., Taub R. N., Baker M. A., Bhalla K., Gervasoni J., Rosado J. E. M., Stewart V., Krishna S., Hindenburg A. A., Cancer Res., 49, 4120-4125 (1989).

25) Akan I., Akan S., Akca H., Savas B., Ozben T., Eur. J. Clin. Invest., 34, 683-689 (2004).

26) Choi C. H., Cancer Cell Int., 5, 30-35 (2005).

27) Ozben T., FEBS Lett., 580, 2903-2909 (2006)

28) Leonard G. D., Fojo T., Bates S. E., Oncologist, 8, $411-424$ (2003).

29) Liscovitch M., Lavie Y., Cancer multidrug resistance: a review of recent drug discovery research, IDrugs, 5, 349-355 (2002).

30) Hunter J., Jepson M. A., Tsuruo T., Simmons N. L., Hirst B. H., J. Biol. Chem., 268, 14991-14997 (1993).

31) Loe D. W., Almquist K. C., Deeley R. G., Cole S. P., J. Biol. Chem., 271, 9675-9682 (1996).

32) Rappa G., Lorico A., Flavell R. A., Sartorelli A. C., Cancer Res., 57 5232-5237 (1997)

33) Renes J., Vries de E. G., Nienhuis E. F., Jansen P. L., Muller M., Br. J. Pharmacol., 126, 681-688 (1999).

34) Salerno M., Garnier-Suillerot A., Eur. J. Pharmacol., 421, 1-9 (2001).

35) Evers R., Kool M., Smith A. J., Deemter van L., Haas de M., Borst P., Br. J. Cancer, 83, 366-374 (2000).

36) Rebbeor J. F., Connolly G. C., Ballatori N., Biochim. Biophys. Acta, 1559, 171-178 (2002)

37) Loe D. W., Oleschuk C. J., Deeley R. G., Cole S. P., Biochem. Biophys Res. Commun., 275, 795-803 (2000).

38) Mao Q., Deeley R. G., Cole S. P., J. Biol. Chem., 275, 34166-34172 (2000).

39) Loe D. W., Deeley R. G., Cole S. P., J. Pharmacol. Exp. Ther, 293 $530-538$ (2000).

40) Trompier D., Chang X. B., Barattin R., du Moulinet D'Hardemare A., Di Pietro A., Baubichon-Cortay H., Cancer Res., 64, 4950-4956 (2004).

41) Muñoz-Martínez F., Lu P., Cortés-Selva F., Pérez-Victoria J. M., Jiménez I. A., Ravelo A. G., Sharom F. J., Gamarro F., Castanys S., Cancer Res., 64, 7130_-7138 (2004).

42) Hu Y. P., Lin J., Wang Q. D., Yie Q. X., Zhang T. M., Yao Xue Xue Bao, 28, 75-78 (1993). 